\title{
The effects of timing and rate of marine cloud brightening aerosol injection on albedo changes during the diurnal cycle of marine stratocumulus clouds
}

\author{
A. K. L. Jenkins, P. M. Forster, and L. S. Jackson \\ School of Earth and Environment, University of Leeds, Leeds, UK \\ Correspondence to: A. K. L. Jenkins (eeaklj@leeds.ac.uk) \\ Received: 30 July 2012 - Published in Atmos. Chem. Phys. Discuss.: 17 September 2012 \\ Revised: 18 December 2012 - Accepted: 1 February 2013 - Published: 8 February 2013
}

\begin{abstract}
The marine-cloud brightening geoengineering technique has been suggested as a possible means of counteracting the positive radiative forcing associated with anthropogenic atmospheric $\mathrm{CO}_{2}$ increases. The focus of this study is to quantify the albedo response to aerosols injected into marine stratocumulus cloud from a point source at different times of day. We use a cloud-resolving model to investigate both weakly precipitating and non-precipitating regimes. Injection into both regimes induces a first indirect aerosol effect. Additionally, the weakly precipitating regime shows evidence of liquid water path gain associated with a second indirect aerosol effect that contributes to a more negative radiative forcing, and cloud changes indicative of a regime change to more persistent cloud. This results in a cloud albedo increase up to six times larger than in the nonprecipitating case. These indirect effects show considerable variation with injection at different times in the diurnal cycle. For the weakly precipitating case, aerosol injection results in domain average increases in cloud albedo of 0.28 and 0.17 in the early and mid morning (03:00:00 local time (LT) and 08:00:00 LT respectively) and 0.01 in the evening (18:00:00 LT). No cloud develops when injecting into the cloud-free early afternoon (13:00:00 LT). However, the all-sky albedo increases (which include both the indirect and direct aerosol effects) are highest for early morning injection (0.11). Midmorning and daytime injections produce increases of 0.06 , with the direct aerosol effect compensating for the lack of cloud albedo perturbation during the cloud-free early afternoon. Evening injection results in an increase of 0.04. For the weakly precipitating case considered, the optimal injection time for planetary albedo response is the early morn-
\end{abstract}

ing. Here, the cloud has more opportunity develop into a more persistent non-precipitating regime prior to the dissipative effects of solar heating. The effectiveness of the seaspray injection method is highly sensitive to diurnal injection time and the direct aerosol effect of an intense aerosol point source. Studies which ignore these factors could overstate the effectiveness of the marine cloud brightening technique.

\section{Introduction}

Geoengineering schemes have been proposed that decrease the amount of solar radiation reaching the Earth's surface, creating a cooling effect that could potentially ameliorate future greenhouse gas driven warming (Lenton and Vaughan, 2009). One such scheme, the marine-cloud brightening geoengineering proposal (Latham, 1990, 2002), aims to brighten low cloud, generating a negative radiative forcing from the cloud albedo increase. The original proposal assumed that this albedo increase could be achieved by the deliberate enhancement of the indirect aerosol effect through the injection of aerosols into the marine boundary layer from unmanned wind-powered vessels (Salter et al., 2008).

Marine cloud brightening has been simulated in both Global Circulation Models (GCMs) and higher resolution cloud-resolving models. GCMs have difficulty representing the highly inhomogeneous aerosol concentration associated with aerosol injection from a single spraying vessel, but are able to simulate the large-scale response of the atmosphere and ocean (when combined with an ocean model). First investigations increased the cloud droplet number 
concentrations $\left(N_{\mathrm{d}}\right)$ for low-level clouds to a fixed value of $375 \mathrm{~cm}^{-3}$ and found forcings ranged from $-0.97 \mathrm{~W} \mathrm{~m}^{-2}$ for three regions of persistent marine stratocumulus (Jones et al., 2009) to $-8.0 \mathrm{~W} \mathrm{~m}^{-2}$ for adjustment of all low-level maritime cloud (Latham et al., 2008). These simulations also found significant regional climate change that was not offset and also found varying sensitivities of different climate variables (Rasch et al., 2009). For example, precipitation decreases of up to $1 \mathrm{~mm}$ day $^{-1}$ have been simulated in the Amazon when cloud drop concentrations were changed (Jones et al., 2009, 2011a).

Global aerosol and climate-aerosol model simulations moved away from the fixed assumed $N_{\mathrm{d}}$, basing the input aerosol injection rates on design characteristics of the proposed wind-powered sea-water spray pumping vessels (Salter et al., 2008). These simulations resulted in maximum $N_{\mathrm{d}}$ of $177 \mathrm{~cm}^{-3}$ (Korhonen et al., 2010) and $286 \mathrm{~cm}^{-3}$ (Partanen et al., 2012) in the injected regions. Based on similar injection areas as Jones et al. (2009), Partanen et al. (2012) calculated a global mean radiative forcing of $-0.8 \mathrm{~W} \mathrm{~m}^{-2}$ which included a $-0.1 \mathrm{~W} \mathrm{~m}^{-2}$ direct aerosol effect, resulting largely from areas of low cloud cover. Whilst the increasingly complex global models are able to represent interactions between injected aerosols, background aerosols, clouds and the climate, large uncertainties remain, especially at the cloud process scale (Wang and Feingold, 2009a, b). Aerosol injection processes and marine stratocumulus (MSc) dynamical processes occur at scales of tens of meters, and therefore can only be examined in detail using cloud-resolving models.

Using a cloud-resolving large-eddy simulation (LES), Wang et al. (2011) found that the albedo response to aerosol injection is regime dependent. Heavy precipitation largely scavenging out the injected aerosol, whilst heavily polluted clouds showed little albedo change owing to the already high albedo. Dry regimes offset increased $N_{\mathrm{d}}$ with losses from increased evaporation of the smaller particles. Only weakly precipitating regimes and low $\mathrm{CCN}$ conditions (possibly following heavy precipitation) were effectively altered by aerosol injection. The emission of aerosols into individual grid cells (rather than a uniform aerosol increase over the domain as a whole) was used to simulate aerosol emission from individual spraying vessels. This technique, hereinafter described as point source injection, was found to induce complex dynamical feedbacks in precipitating regimes - associated with the buffered-system nature of clouds (Stevens and Feingold, 2009) - and a spatially inhomogeneous albedo response. This small-scale inhomogeneity deviates from the inherent uniformity of both aerosol injection and cloud response of global scale models.

The diurnal cycle of MSc in GCMs is produced using parameterisations (for example, of entrainment). The simulated diurnal cycle is thus sensitive to the performance of these parameterisations (e.g. Lock, 2004; Johnson, 2005; and Chlond et al., 2004). The diurnal cycle of MSc in cloud-resolving models is produced through the explicit handling of physi- cal processes, and thus is not prone to problems associated with the parameterised representations. The MSc diurnal cycle is caused by short-wave (SW) solar insolation. The resulting SW in-cloud warming offsets the long-wave (LW) cloudtop radiative cooling and therefore reduces the turbulence that sustains the cloud (Nieuwstadt and Duynkerke, 1996; Duynkerke and Teixeira, 2001; Duynkerke et al., 2004). MSc therefore typically exhibit decoupling of the cloud and subcloud layers and cloud dissipation during daylight. The extent of this is dependent on conditions, but is evident in losses in both cloud liquid water path (LWP) and cloud fraction (Duynkerke and Teixeira, 2001; Bretherton et al., 2004; Duynkerke et al., 2004). As the warming effect of the SW radiation stops during the night, the cloud can recover (Wang et al., 2010). Hence, in addition to the range of cloud conditions produced by background atmospheric and background aerosol conditions, further variation will occur through the diurnal cycle. Cloud-resolving simulations of the effects of aerosol injection into different cloud conditions have assumed repeated aerosol injection throughout the day (Wang et al., 2011) and have not investigated the effect of timing of aerosol injection during the diurnal cycle on planetary albedo change effectiveness.

This study investigates the efficacy of aerosol injection on both cloud albedo and all-sky albedo increases, with injection at different times in the diurnal cycle, and at three different aerosol injection rates. The effect is quantified for both weakly precipitating (WP) and non-precipitating (NP) regimes. From this, the optimal time of day to inject aerosols is identified.

We quantify the contribution of the direct aerosol effect and how this direct effect interacts with the indirect effect associated with changes in cloud albedo.

\section{Model set-up}

We use the Weather Research and Forecasting model coupled with Chemistry (WRF/Chem) V3.3.1 (Skamarock et al., 2008) in the large-eddy simulation (LES) configuration. This model incorporates interactive chemistry through the Carbon Bond Mechanism - Z (CBMZ) gas phase chemical mechanism scheme (Zaveri and Peters, 1999; Fast et al., 2006) and aerosol processes through the 8-bin MOSAIC scheme (Zaveri et al., 2008). Aerosols interact with the cloud through the Morrison et al. (2005) two-moment microphysics scheme, which includes cloud droplet sedimentation. Activation of aerosols to cloud droplets follows the Abdul-Razzak and Ghan (2000) method. LW radiation calculations were performed by the CAM spectral-band LW scheme (Collins et al., 2004). SW radiation calculations were performed by the RRTMG transfer scheme. Sensitivity tests using this combination of radiation schemes produced patterns of longwave cloud-top radiative cooling, daytime short-wave warming and resulting cloud properties that are characteristic of 
MSc cloud diurnal behaviour (discussed further in the Results section). The 1.5 order 3-D turbulent kinetic energy closure scheme (Skamarock et al., 2008) was utilised to simulate sub-grid turbulence. Advection was constrained by the monotonic flux limiter option (Wang et al., 2009). Surface layer physical processes were represented by the MoninObukov scheme. Horizontal boundary conditions were periodic, and a $250 \mathrm{~m}$ damping layer was included at the model top. Subsidence was included through a large-scale horizontal divergence of $3.75 \times 10^{-6} \mathrm{~s}^{-1}$. Large-scale wind was initialised at zero (following Wang and Feingold, 2009a and Wang et al., 2011).

Input soundings follow Research Flight 02 (RF02) of the DYCOMS-II field campaign which observed drizzling stratocumulus (Ackerman et al., 2009). The inversion height was $795 \mathrm{~m}$. Total water mixing ratio was initialised at $9.45 \mathrm{~g} \mathrm{~kg}^{-1}$ in the boundary layer, decreasing to $5.0 \mathrm{~g} \mathrm{~kg}^{-1}$ in the free troposphere. The potential temperature was initialised to $288.3 \mathrm{~K}$ in the boundary layer, increasing to $303.9 \mathrm{~K}$ by 1500 $\mathrm{m}$ height. Comparability to previous simulations or observations of the RF02 case (Ackerman et al., 2009) is not expected however, owing to differences between initialisations (for example, background aerosol distributions and largescale wind). In order to produce three control cases reproducing a range of stratocumulus cloud conditions, three background aerosol concentration initialisations for $\mathrm{SO}_{4}, \mathrm{NH}_{4}$, $\mathrm{NO}_{3}, \mathrm{Na}, \mathrm{Cl}$, black carbon and organic carbon were selected from model output of the global atmospheric aerosol and chemistry GLOMAP model (Mann et al., 2010). The three representative aerosol locations chosen were: the Southern Ocean, a pristine case; the North-East Pacific, the location of the Second Dynamics and Chemistry of Marine Stratocumulus (DYCOMS-II) mission (Stevens et al., 2003) and an area of persistent MSc cloud; and the East China Sea, an area of high atmospheric aerosol concentration resulting from mainly anthropogenic sources. The 8-bin size distributions for these background aerosol initialisations are presented in Fig. 1.

The background aerosol budget comprised a natural winddriven sea-spray source (Fuentes et al., 2010); activation of background and emitted gases; and a wet deposition sink. The gases $\mathrm{SO}_{2}, \mathrm{H}_{2} \mathrm{O}_{2}, \mathrm{NH}_{3}, \mathrm{CO}$ and $\mathrm{O}_{3}$ were initialised with values typical of the oceanic boundary layer atmosphere in regions of MSc (Georgii and Gravenhorst, 1977; Khalil and Rasmussen, 1994; Kazil et al., 2011). The concentration of $\mathrm{SO}_{2}$ was increased by $1.0 \mathrm{pptv} \mathrm{h}^{-1}$ in order to represent the processes associated with dimethyl sulphide, in lieu of an explicit scheme, following the observations and modelling of Gray et al. (2011) and Yang et al. (2011).

The wet deposition scheme used does not allow for resuspension of aerosols during the evaporation of rain droplets and hence is likely to lead to an overly strong aerosol sink (Saide et al., 2012).

The horizontal domain size was $9 \mathrm{~km} \times 9 \mathrm{~km}$ with grid cell resolution of $300 \mathrm{~m}$. The model extends $1.5 \mathrm{~km}$ vertically,

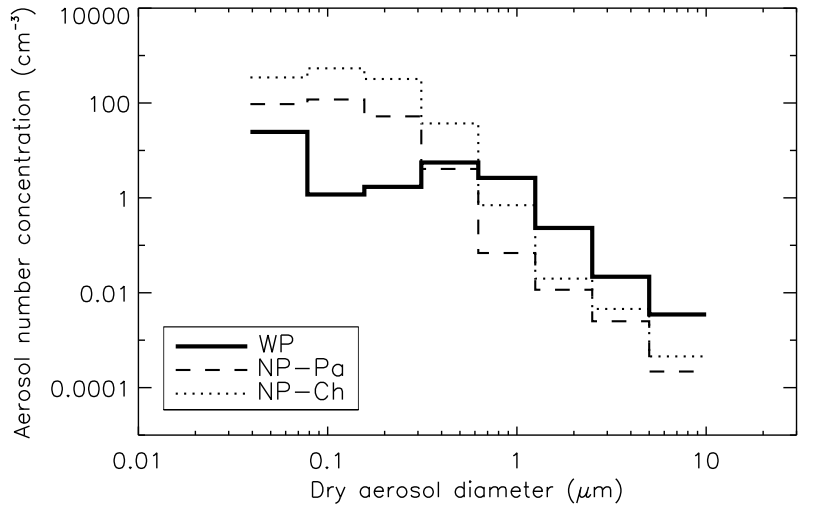

Fig. 1. Background aerosol initialisation for the three control cases: WP, NP-Pa and NP-Ch.

with 50 vertical layers (increasing in depth with height). Each control case was simulated for $35 \mathrm{~h}$, starting at 22:00:00 local time (LT) on 21 July 2001. The sun rose at 05:20:00 LT, and set at 19:00:00 LT. Control case results are presented inclusive of the spin-up period. The choice of relatively coarse horizontal resolution follows Wang and Feingold (2009a) and has been used in subsequent modelling studies (Wang et al., 2011). Analysis of the post-injection simulations is limited to the five hour period subsequent to injection. After this time, the aerosols pervade the domain. Selecting a relatively small horizontal domain allows us to perform detailed analysis of the aerosol injection, aerosol interaction with clouds, and rapid cloud response within our computational constraints. It does however preclude the representation of mesoscale features associated with MSc cloud decks (e.g. Wood and Hartmann, 2006; Wood et al., 2008) and secondary circulations that can be triggered by aerosol concentration gradients (e.g. Wang and Feingold, 2009a, b; Feingold et al., 2010; Wang et al., 2011). Despite these exclusions, the variations in simulated cloud properties are consistent with characteristic changes in radiative and dynamical features of the stratocumulus topped boundary layer over the diurnal cycle (discussed further in the Results and Discussion sections), and follow the similar or smaller domain sizes that have previously been used to study the behaviour of marine stratocumulus clouds (e.g. Stevens et al., 2005; Ackerman et al., 2009) and their sensitivities to atmospheric variables over the diurnal cycle (Chen et al., 2011).

\section{Experimental design}

For each of the three background aerosol concentrations, four aerosol injection simulations were performed, corresponding to aerosol injection in the early morning (03:00:00 LT), mid-morning (08:00:00 LT), day (13:00:00 LT) and evening (18:00:00 LT). These times represent injection into the various conditions of the diurnally varying MSc. Additional 
experiments investigated the effects of varying the aerosol injection rate and were carried out for weakly precipitating conditions only.

The spraying vessel was assumed to travel the length of the $9 \mathrm{~km}$ domain once, along the middle of the domain, at a speed of $5 \mathrm{~m} \mathrm{~s}^{-1}$. This moving aerosol injection was simulated as an increase in $\mathrm{Na}$ and $\mathrm{Cl}$ aerosol in one base-layer grid cell at a time. This follows Wang et al. (2011) in simulating the point source aerosol emission from individual spraying vessels. It is noted that whilst this uniform emission within the $300 \mathrm{~m} \times 300 \mathrm{~m}$ grid cell is still two orders of magnitude larger than the 2.4 diameter emission rotors proposed by Salter et al. (2008), it is more realistic than a uniform aerosol emission over the whole domain. The mass and number fluxes were based on injection rates estimated by Salter et al. (2008) with an injection rate of $30 \mathrm{~kg} \mathrm{~s}^{-1}$ of sea water forming a wet spray of $800 \mathrm{~nm}$ diameter. As such, these aerosols were emitted into the third size bin, representing a dry diameter one quarter of the diameter of the wet droplets (Lewis and Schwartz, 2004), i.e. $200 \mathrm{~nm}$. The number flux $\left(1.24 \times 10^{12} \mathrm{~m}^{-2} \mathrm{~s}^{-1}\right)$ was calculated as the number of $800 \mathrm{~nm}$ diameter sea water droplets (assumed to be spherical) produced for the $30 \mathrm{~kg} \mathrm{~s}^{-1}$ sea water flux. The mass fluxes of $\mathrm{Na}$ and $\mathrm{Cl}\left(4436 \mu \mathrm{g} \mathrm{m} \mathrm{m}^{-2} \mathrm{~s}^{-1}\right.$ and $6840 \mu \mathrm{g} \mathrm{m}^{-2} \mathrm{~s}^{-1}$ respectively) were calculated by assuming a $200 \mathrm{~nm}$ dry salt diameter, assuming that the fraction of $\mathrm{Na}$ and $\mathrm{Cl}$ follows the ratio of atomic weights $(23.00: 35.45)$. In preliminary testing, it was found that injection rates greater than half the mass and number fluxes of Salter's full emission rate resulted in unphysical outputs from the SW radiation scheme, ultimately leading to simulation failure. Given that the Salter et al. (2008) injection rate is dependent on the wind speed and decreases at speeds below 6-8 $\mathrm{m} \mathrm{s}^{-1}$ (Korhonen et al., 2010), and that half of the maximum Salter injection rate (denoted as SA0.5) produced clear perturbations in the cloud and cloud system, this will be the maximum injection rate used. Experiments to investigate the effects of varying the aerosol injection rate on the weakly precipitating case consisted of injecting a quarter of the Salter injection rate (SA0.25) and a tenth of the Salter rate (SA0.1) at each of the four times through the diurnal cycle. The aerosol injection experiments are summarised in Table 1.

\section{Results}

Of the three background aerosol concentrations, the pristine marine conditions of the Southern Ocean produced a weakly precipitating case (WP). The North-East Pacific location typical for MSc, and the most heavily polluted East China Sea background aerosol conditions both produced non-precipitating regimes (NP-Pa and NP-Ch respectively).
Table 1. Aerosol injection experiments. WP indicates aerosol injection into the weakly precipitating control case. NP-Pa and NP-Ch indicate aerosol injection into the non-precipitating cases initialised with aerosol concentrations associated with the North-East Pacific (intermediately polluted) and the East China Sea (heavily polluted) respectively. SA0.5, SA0.25 and SA0.1 describe the aerosol injection rate, as a fraction of the injection rate proposed by Salter et al. (2008).

\begin{tabular}{llll}
\hline \multirow{2}{*}{$\begin{array}{c}\text { Time of aerosol } \\
\text { injection (LT) }\end{array}$} & \multicolumn{3}{c}{ Aerosol injection rate } \\
\cline { 2 - 4 } & SA0.5 & SA0.25 & SA0.1 \\
\hline 03:00:00 & WP & WP & WP \\
& NP-Pa & - & - \\
& NP-Ch & - & - \\
\hline 08:00:00 & WP & WP & WP \\
& NP-Pa & - & - \\
& NP-Ch & - & - \\
\hline 13:00:00 & WP & WP & WP \\
& NP-Pa & - & - \\
& NP-Ch & - & - \\
\hline 18:00:00 & WP & WP & WP \\
& NP-Pa & - & - \\
& NP-Ch & - & - \\
\hline
\end{tabular}

\subsection{Control cases}

\subsubsection{Weakly precipitating (WP) control case}

This WP control case demonstrated a clear diurnal cycle in both cloud properties (Fig. 2) and dynamical and physical processes (Fig. 3).

Cloud-top LW radiative cooling (Fig. 3c) produced a band of negative buoyancy atop positive cloud layer buoyancy (Fig. 3d). This negative buoyancy produced turbulent kinetic energy (TKE) (Fig. 3e and f) which led to boundary layer mixing (suggested by the vertical velocity variance, Fig. 3a). The SW radiation, present during the day, offset this cloud-top cooling, reducing the TKE and mixing through the boundary layer. The reduced vertical transport of moisture from the surface was evident in an accumulation of total water mixing ratio at the surface during the day (Fig. 3g). As the SW radiation dissipated into the second night, the TKE recovered, allowing improved mixing within the boundary layer. Simulated surface heat fluxes also demonstrated a diurnal cycle, with domain average surface latent heat flux varying between $6 \mathrm{~W} \mathrm{~m}^{-2}$ during the day and a maximum of $10 \mathrm{~W} \mathrm{~m}^{-2}$ during the night. Domain average sensible heat flux was approximately $1 \mathrm{~W} \mathrm{~m}^{-2}$ during the day, reaching a maximum of $4 \mathrm{~W} \mathrm{~m}^{-2}$ during the night. This periodicity in the strength of dynamical and physical processes was reflected in the pattern of cloud properties. During the more turbulent night (and outside of the spin-up period), cloud fraction reached $70 \%$ (Fig. 2e), LWP reached $50 \mathrm{~g} \mathrm{~m}^{-2}$ (Fig. 2c) 

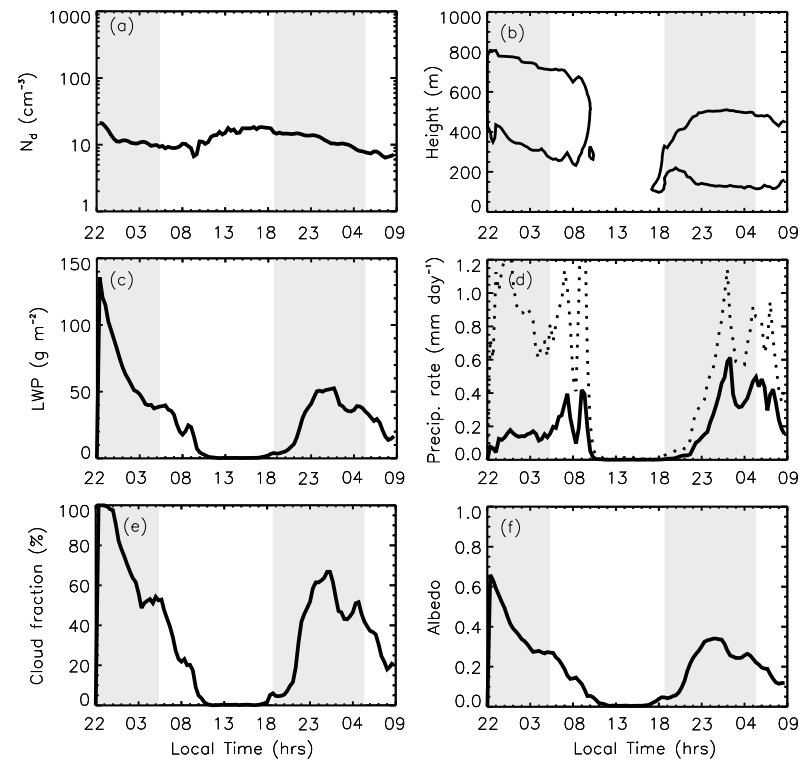

Fig. 2. Time evolution of domain averaged cloud properties for the WP control case. (a) Cloud droplet number concentration $\left(N_{\mathrm{d}}\right.$, $\mathrm{cm}^{-3}$ ); (b) cloud top and cloud base height (contour at cloud water mixing ratio of $0.01 \mathrm{~g} \mathrm{~kg}_{\text {dry air }}^{-1}$ ); (c) liquid water path (LWP, $\mathrm{g}$ $\left.\mathrm{m}^{-2}\right)$; (d) surface rain rate (solid), and cloud base rain rate (dotted) $\left(\mathrm{mm}\right.$ day $\left.^{-1}\right)$; (e) cloud fraction (\%); and (f) cloud albedo. Shading indicates the night.

and the cloud was approximately $400 \mathrm{~m}$ deep (Fig. 2b). In these conditions, the low $N_{\mathrm{d}}$ of around $10 \mathrm{~cm}^{-3}$ produced precipitation (Fig. 2a and d). The peak surface precipitation rate was $0.6 \mathrm{~mm} \mathrm{day}^{-1}$, whilst the cloud base rate at this time was nearly $1.2 \mathrm{~mm} \mathrm{day}^{-1}$ (Fig. $2 \mathrm{~d}$ ). The domain average calculated cloud albedo reached 0.35 during the night (Fig. 2f). Even during the night, the cloud and boundary layers were not well coupled. Turbulence was largely confined to the cloud layer, as was vertical velocity variance, and the boundary layer became stratified (Fig. 3g). During the daytime, the continuation of precipitation, augmented by the inhibition of moisture transport to the cloud region in the less turbulent conditions resulted in loss of supersaturation below the inversion. Therefore, for the combination of radiative and thermodynamic conditions established by this formation of atmospheric conditions, cloud formation abated and cloud fraction, LWP, precipitation and albedo fell to zero. For this WP case, there was a period of approximately $6 \mathrm{~h}$ during the day between cloud dissipation and cloud recovery. Satellite observations suggest that this total cloud dissipation is atypical for marine stratocumulus clouds (Rozendaal et al., 1995; Stubenrauch et al., 2006). Daytime cloud dissipation has however been observed during aircraft/ground based field campaigns (Albrecht et al., 1988; Minnis et al., 1992), suggesting that its occurrence is more likely over small, lo-
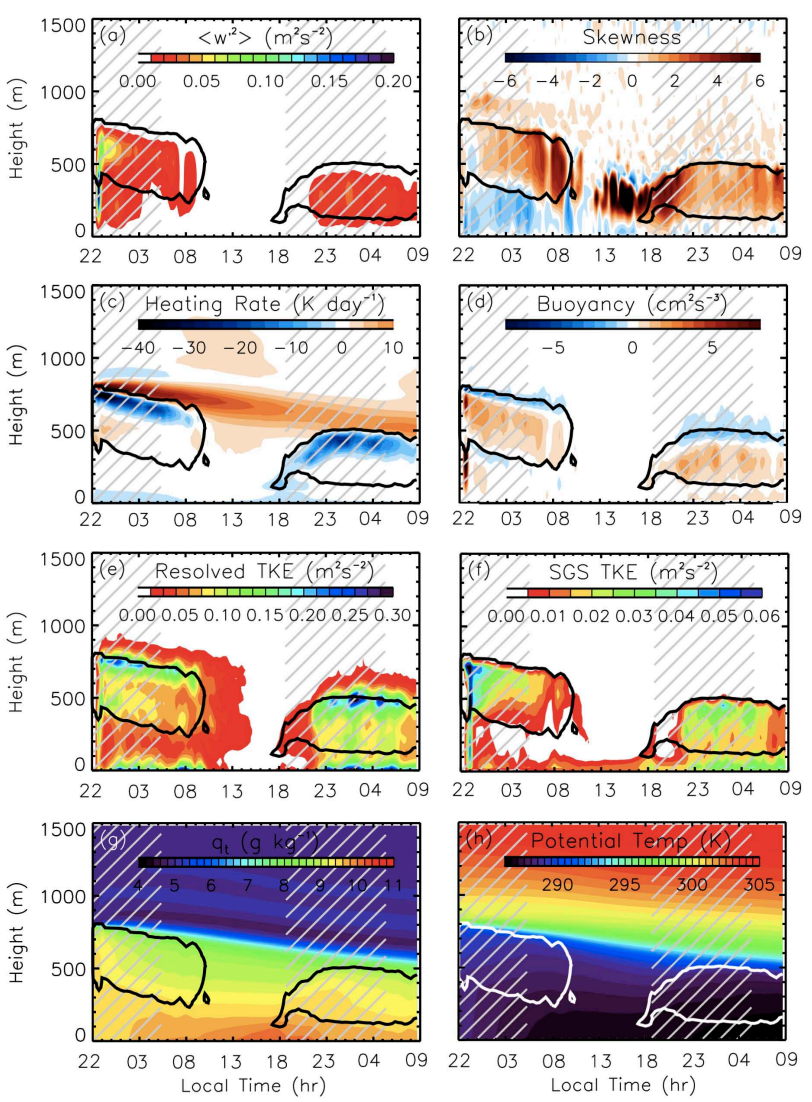

Fig. 3. Time evolution of domain averaged dynamic and physical properties for the WP control case. (a) Vertical velocity variance $\left(<w^{\prime 2}>, \mathrm{m}^{2} \mathrm{~s}^{-2}\right)$; (b) vertical velocity skewness; (c) radiative heating rate $\left(\mathrm{K} \mathrm{day}^{-1}\right)$; (d) buoyancy $\left(\mathrm{cm}^{2} \mathrm{~s}^{-3}\right)$; (e) resolved turbulent kinetic energy $\left(\mathrm{m}^{2} \mathrm{~s}^{-2}\right)$; (f) sub-grid scale turbulent kinetic energy $\left(\mathrm{m}^{2} \mathrm{~s}^{-2}\right)$; (g) total water mixing ratio $\left(\mathrm{g} \mathrm{kg}_{\text {dry air }}^{-1}\right)$; and (h) potential temperature (K). Solid lines indicate the cloud top and cloud base height (a contour at cloud water mixing ratio of $0.01 \mathrm{~g} \mathrm{~kg}_{\text {dry air }}^{-1}$ ). Hatch lines indicates the night.

calised areas rather than being evident as a mean cloud property over tens or hundreds of square kilometres.

Over the $35 \mathrm{~h}$ long control simulation, cloud top and cloud base heights decreased (by approximately $350 \mathrm{~m}$ and $300 \mathrm{~m}$ respectively).

\subsubsection{Non-precipitating (NP) control cases}

Similar to the WP case, the NP cases also showed clear diurnal patterns in cloud properties (Fig. 4) and physical and dynamical processes (Fig. 5).

The background aerosol concentration initialisations led to cloud average $N_{\mathrm{d}}$ of almost $200 \mathrm{~cm}^{-3}$ for NP-Pa and around $500 \mathrm{~cm}^{-3}$ for NP-Ch case. In both cases, the $N_{\mathrm{d}}$ was sufficient to inhibit precipitation formation (Fig. 4d).

As in the WP case, LW cloud-top radiative cooling (Fig. 5c) produced a band of negative buoyancy at the cloud 

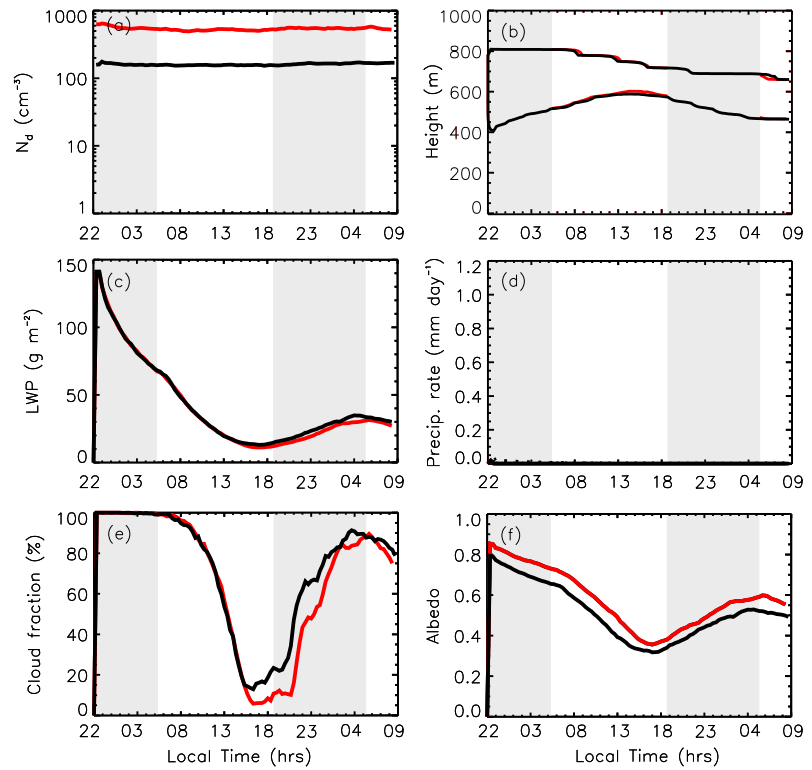

Fig. 4. Time evolution of domain averaged cloud properties for the NP-Ch (red) and NP-Pa (black) cases. Descriptions as Fig. 2.

top (Fig. 5d) that resulted in TKE (Fig. 5e and f). Cloudtop radiative cooling was stronger in the NP case than in the WP case, resulting in a stronger vertical velocity variance (Fig. 5a) and a better mixed/less stratified boundary layer (Fig. 5g). Simulated surface heat fluxes again demonstrated a diurnal cycle, with domain average latent heat flux reaching approximately $10 \mathrm{~W} \mathrm{~m}^{-2}$ during the night, from approximately $3 \mathrm{~W} \mathrm{~m}^{-2}$ during the day. Domain average sensible heat fluxes remained at approximately $0 \mathrm{~W} \mathrm{~m}^{-2}$ during the day and night. Whilst SW radiation during the day again heated the clouds (subduing cloud-top LW radiative cooling and negative buoyancy) they did not fully dissipate. Thus, although weakened during the day, these dynamical and physical processes were maintained over the diurnal cycle.

The diurnal cycle was again seen in the cloud properties. Unlike the total loss of LWP during the day seen in the WP case, the minimum LWP for both of the NP cases was approximately $10 \mathrm{~g} \mathrm{~m}^{-2}$. This recovered to around $35 \mathrm{~g} \mathrm{~m}^{-2}$ (NP-Pa) and $30 \mathrm{~g} \mathrm{~m}^{-2}$ (NP-Ch) during the subsequent night (Fig. 4c). Similarly, whereas the daytime cloud fraction in the WP case fell to zero, in the NP cases this minimum was maintained at $15 \%$ for NP-Pa, and $5 \%$ for NP-Ch, recovering to $90 \%$ for both cases into the night (Fig. 4e). Cloud was also maintained at a higher fraction for longer, with slower dissipation into the day, and a shorter period of low cloud fraction. Owing to the inverse relationship between cloud droplet radius and optical thickness, the higher cloud average $N_{\mathrm{d}}$ for NP-Ch caused the domain average calculated cloud albedo to be consistently higher than the NP-Pa case, despite the lower cloud fraction and LWP values (Fig. 4f). This cloud albedo also showed a diurnal cycle, ranging from approxi-
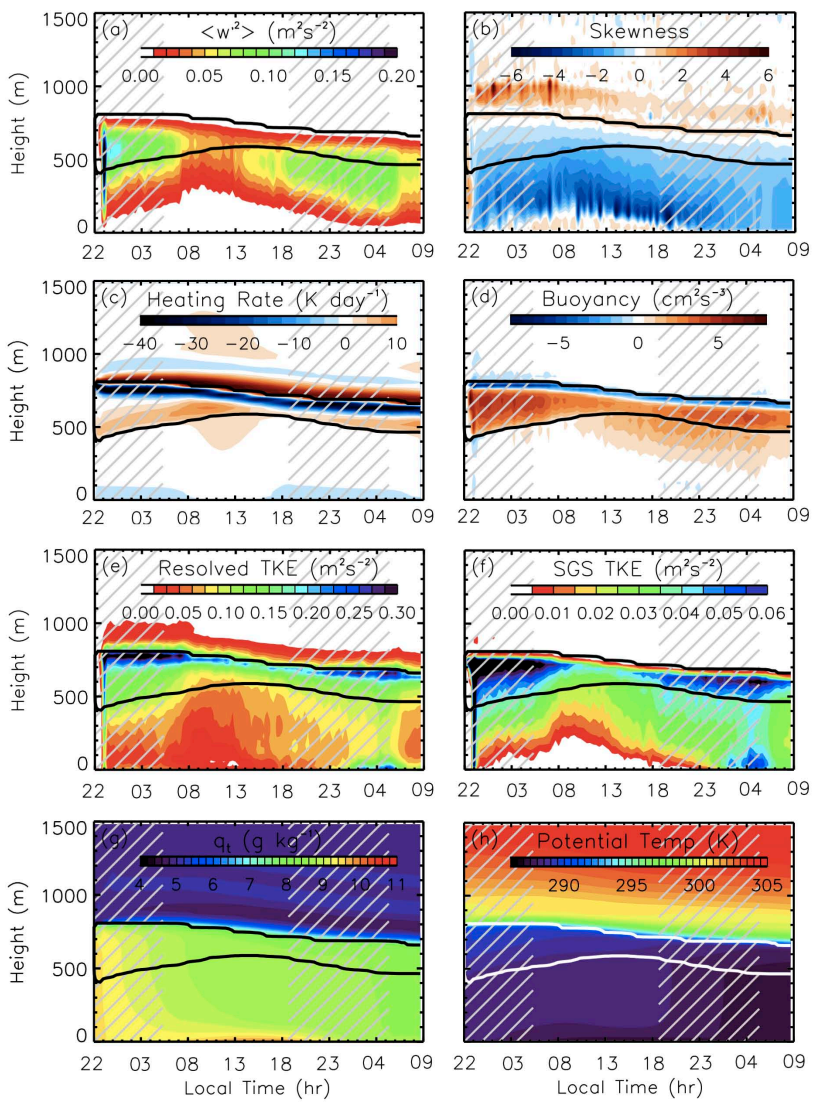

Fig. 5. Time evolution of domain averaged dynamic and physical properties for NP-Pa control case. Descriptions as Fig. 3.

mately 0.35 to 0.6 for the day and night time values in NP-Ch and from approximately 0.3 to 0.5 for NP-Pa.

Cloud-top height decreased by $150 \mathrm{~m}$ over the $35 \mathrm{~h}$ simulation, with the decrease being more exaggerated during the day as turbulence levels decrease. There was additionally a diurnal cycle in cloud base height, with the base rising during the day, causing cloud thinning to around $100 \mathrm{~m}$. The cloud doubled in thickness during the night. These cloud height properties were similar for both NP cases.

Whilst there were some similarities between processes in the WP and NP clouds (albeit of differing strength), one area of disparity was the vertical velocity skewness - a measure of the relative strengths of updrafts and downdrafts (Figs. 3b and $5 \mathrm{~b}$ ). In the NP control cases, strong downdrafts driven by the cloud top LW radiative cooling descended towards the surface, producing a negative skewness throughout the boundary layer. This was in contrast to the WP case, which showed positive skewness within the cloud layer, and negative skewness below.

The diurnal patterns shown in the control cases were similar to previous simulations of the diurnal cycle in marine stratocumulus. For example, LWP magnitudes were similar to those achieved in the simulations of Wang and Feingold 
(2009a), Wang et al. (2011), and Chen et al. (2011). Whilst the LWP magnitudes were lower than the range of measurements in the DYCOMS-II (RF02) case (90 to $120 \mathrm{~g} \mathrm{~m}^{-2}$ ), on which the input soundings of these simulations were based, it is noted that the DYCOMS-II measurements assume an average over open and closed cells, and aerosol concentrations differ from the observed conditions. Other features of the control cases suggest typical MSc behaviour. Negative vertical velocity skewness in the NP cases, peaking in the lower third of the boundary layer, agrees with the observations of Hogan et al. (2009). The positive skewness within the cloud in the WP case being consistent with wide downward motions associated with droplet sedimentation within the cloud (Ackerman et al., 2009) and strong, narrow downdrafts, associated with precipitation below the cloud (Wang and Feingold, 2009a). Additionally, the stratification observed in the total water mixing ratio of the WP case suggests uncoupling of the cloud and boundary layers (Jones et al., 2011b) which is typical of precipitating MSc.

While cloud conditions do not recover fully into the second night owing to imbalances in forcings, the clear diurnal patterns in cloud properties and - importantly - in underlying cloud system physics and dynamics allows the cloud response to aerosol injection to be related to the characteristic physical status of the cloud system at different times of the diurnal cycle.

\subsection{The effect of aerosol injection}

The effects of aerosol injection on albedo were considered by three measures.

1. $\left(\Delta \alpha_{\mathrm{CC}}\right)$ The change in domain average cloud albedo for times of SW radiation in the $5 \mathrm{~h}$ subsequent to injection compared to the control. This uses the simplified calculation of Twomey (1977) for optical cloud thickness, $\tau=2 \pi N \bar{r}^{2} h$, where $N$ is the drop concentration, $\bar{r}=\mathrm{a}$ representative mean radius calculated from the mass of liquid water and droplet concentration at each grid cell, and $h$ is the depth of the grid cell. This was then converted into albedo $(A)$ using the approximation, $A=\tau /(6.8+\tau)$ (Lacis and Hansen, 1974; Zhang et al., 2005). An estimation of the aerosol effect on cloud albedo in the absence of LWP increase was also included (i.e. a fixed LWP assumption, $\Delta \alpha_{\text {CC_fixed_LWP), }}$ whereby the calculation was repeated with control case LWP and increase in $N_{\mathrm{d}}$ weighted for this control case LWP.

2. $\left(\Delta \alpha_{\mathrm{AS}}\right)$ The domain average change in all-sky planetary albedo for times of SW radiation in the $5 \mathrm{~h}$ subsequent to injection compared to the control was calculated as the ratio of upward to downward SW radiation at the top of atmosphere. This incorporates the concurrent effects of both cloud albedo change and direct aerosol effects, over a constantly low ocean surface albedo.
3. $\left(\Delta \alpha_{\mathrm{CS}}\right)$ The domain average change in clear-sky albedo for times of SW radiation in the $5 \mathrm{~h}$ subsequent to injection compared to the control was calculated. This calculates the albedo for all columns in the domain, omitting cloud layer effects. Therefore, the masking effect of overlying clouds is removed, and $\Delta \alpha_{\mathrm{CS}}$ is a measure of the maximum direct aerosol effect.

Since the brightening of clouds is only effective at producing a negative radiative perturbation during daylight, all measures of albedo were calculated only when downward SW radiation is present. As such, the early morning and evening injection times have a reduced analysis period. Injection into the early morning captures the latter portion of cloud alterations, while the injection into the evening captures only 40 min after the beginning of injection.

\subsubsection{Aerosol injection into WP case}

We initially consider the response of the WP case to SA0.5 injection of aerosol at the four different points during the diurnal cycle.

The cloud average $N_{\mathrm{d}}$ increased in response to injection at all four times during the diurnal cycle. This increase ranged from a five-fold increase (to $117 \mathrm{~cm}^{-3}$ ) for injection into the low cloud fraction during the day (13:00:00 LT), to an increase of almost 17 times the original concentration (to $234 \mathrm{~cm}^{-3}$ ) for injection in the mid-morning (08:00:00 LT) (Table 2). These $N_{\mathrm{d}}$ increases were sufficient to reduce the domain mean precipitation rate by up to $88 \%$ averaged over the time where SW radiation was present in the $5 \mathrm{~h}$ subsequent to injection. However, no change occurred for injection into the cloud-free early afternoon at which time background precipitation has already ceased, or for evening injection (18:00:00 LT) where precipitation rates had not yet recovered. The precipitation decreases produced an increase in LWP compared to the control case of $43 \%$ for early morning injection (03:00:00 LT), and 114\% for mid-morning injection. In addition to LWP increases, injecting aerosols into cloudy conditions resulted in an increase in cloud fraction. Early morning injection doubled the cloud fraction while mid-morning injection tripled the cloud fraction. The cloud fraction, and associated perturbations were negligible for day and evening injections. Aerosol injection also affected the cloud height, particularly when injected into the dissipating cloud in the early and mid mornings. Here, the cloud top descent seen in the control case was replaced by cloud top height maintenance (Fig. 6). A slight cloud top increase was also seen for evening injection, although as this is into the post-SW growth phase of the cloud, the perturbation is less marked. Again, no cloud changes occurred when injecting into the cloud-free early afternoon.

Considering how these changes to cloud properties are related to albedo, Fig. 7 shows the $\Delta \alpha_{\mathrm{CC}}, \Delta \alpha_{\mathrm{AS}}$ and $\Delta \alpha_{\mathrm{CS}}$ for an aerosol injection rate of SA0.5. There is a clear variation 
Table 2. Results for the SA0.5 aerosol injection rate. Domain and time-period averaged liquid water path (LWP, $\left.\mathrm{g} \mathrm{m}^{-2}\right)$, cloud fraction $\left(f_{\mathrm{c}}\right.$, $\%)$, cloud droplet number concentration $\left(N_{\mathrm{d}}, \mathrm{cm}^{-3}\right)$ and surface rain rate $\left(R_{\mathrm{r}}, \mathrm{mm}\right.$ day $\left.^{-1}\right)$. The time average is taken for the times of $\mathrm{SW}$ radiation present in the $5 \mathrm{~h}$ subsequent to aerosol injection.

\begin{tabular}{|c|c|c|c|c|c|c|c|c|c|}
\hline \multirow[t]{2}{*}{ Case } & \multirow{2}{*}{$\begin{array}{l}\text { Time of aerosol } \\
\text { injection (LT) }\end{array}$} & \multicolumn{2}{|c|}{ LWP, $\mathrm{g} \mathrm{m}^{-2}$} & \multicolumn{2}{|c|}{$f_{\mathrm{c}}, \%$} & \multicolumn{2}{|c|}{$N_{\mathrm{d}}, \mathrm{cm}^{-3}$} & \multicolumn{2}{|c|}{$R_{\mathrm{r}}, \mathrm{mm}_{\text {day }}{ }^{-1}$} \\
\hline & & Control & SA0.5 & Control & SA0.5 & Control & SA0.5 & Control & SA 0.5 \\
\hline \multirow[t]{4}{*}{ WP } & 03:00:00 & 31.8 & 45.3 & 37.9 & 76.3 & 10.8 & 176.3 & 0.25 & 0.03 \\
\hline & 08:00:00 & 7.0 & 15.2 & 6.8 & 19.8 & 13.5 & 234.3 & 0.09 & 0.05 \\
\hline & 13:00:00 & 0.6 & 0.5 & 0.4 & 0.3 & 20.6 & 116.9 & 0.00 & 0.00 \\
\hline & 18:00:00 & 3.6 & 3.6 & 5.6 & 5.6 & 19.5 & 171.1 & 0.00 & 0.00 \\
\hline \multirow[t]{4}{*}{ NP-Pa } & 03:00:00 & 59.8 & 60.8 & 97.9 & 98.6 & 156.2 & 315.0 & 0.00 & 0.00 \\
\hline & 08:00:00 & 31.7 & 31.6 & 79.7 & 79.3 & 156.2 & 180.7 & 0.00 & 0.00 \\
\hline & 13:00:00 & 14.8 & 14.8 & 22.9 & 22.7 & 156.5 & 259.8 & 0.00 & 0.00 \\
\hline & 18:00:00 & 14.3 & 14.3 & 22.4 & 22.5 & 156.3 & 178.8 & 0.00 & 0.00 \\
\hline \multirow[t]{4}{*}{ NP-Ch } & 03:00:00 & 59.6 & 59.1 & 98.2 & 98.7 & 526.6 & 632.2 & 0.00 & 0.00 \\
\hline & 08:00:00 & 31.6 & 31.4 & 80.8 & 80.3 & 513.2 & 517.0 & 0.00 & 0.00 \\
\hline & 13:00:00 & 13.4 & 13.7 & 18.8 & 19.1 & 516.9 & 556.1 & 0.00 & 0.00 \\
\hline & 18:00:00 & 11.8 & 11.8 & 9.1 & 9.1 & 528.1 & 528.3 & 0.00 & 0.00 \\
\hline
\end{tabular}

in the $\Delta \alpha_{\mathrm{CC}}$ response for aerosol injections at different times during the diurnal cycle. Early and mid morning injections produced the largest $\Delta \alpha_{\mathrm{CC}}$ of 0.28 and 0.17 respectively. As the cloud recovered into the second night, evening injection produced a slight $\Delta \alpha_{\mathrm{CC}}$ of 0.01 . Whilst there was also a clear variation in both the $\Delta \alpha_{\mathrm{AS}}$ and $\Delta \alpha_{\mathrm{CS}}$ responses for aerosol injection at different times during the diurnal cycle, the pattern was different to that seen in cloud response only. The largest $\Delta \alpha_{\mathrm{AS}}$ was seen for early morning injection at 0.11 , decreasing to 0.06 for mid-morning injection, and decreasing further for evening injection at 0.04 . The clearest of the deviations from the $\Delta \alpha_{\mathrm{CC}}$ pattern was during the cloud-free early afternoon, where the $\Delta \alpha_{\mathrm{AS}}$ was 0.06 . The $\Delta \alpha_{\mathrm{AS}}$ was matched by the $\Delta \alpha_{\mathrm{CS}}$ response at this time, indicating that the $\Delta \alpha_{\mathrm{AS}}$ was purely from the direct aerosol effect. The vertical distribution of the domain maximum unactivated aerosol concentration is shown for each injection time in Fig. 8. The $\Delta \alpha_{\mathrm{CS}}$ also increased the $\Delta \alpha_{\mathrm{AS}}$ more than the $\Delta \alpha_{\mathrm{CC}}$ did for the evening injection where cloud fraction was low. The $\Delta \alpha_{\mathrm{CS}}$ again showed a different diurnal pattern. Early morning injection again produced the largest perturbation of 0.08 , falling to 0.04 for injection in the mid-morning. This recovered into the day, producing a $\Delta \alpha_{\mathrm{CS}}$ of 0.07 . The response was again low for evening injection, producing a $\Delta \alpha_{\mathrm{CS}}$ of 0.02 .

\subsubsection{Aerosol injection into NP cases}

Injection into the NP cases resulted in larger absolute $N_{\mathrm{d}}$ increases than in the WP case (Table 3). Increases were also generally larger for the less polluted NP-Pa case than the more polluted NP-Ch case. The maximum resulting domain and time averaged $N_{\mathrm{d}}$ following injection ranged from $234 \mathrm{~cm}^{-3}$ (WP) to $315 \mathrm{~cm}^{-3}$ (NP-Pa) and $632 \mathrm{~cm}^{-3}$ (NP$\mathrm{Ch})$. These values decreased for injection at the least effec- tive times of day to $117 \mathrm{~cm}^{-3}, 179 \mathrm{~cm}^{-3}$ and $517 \mathrm{~cm}^{-3}$ respectively. It is noted that these averages are for a small domain size, in the time immediately after injection and should therefore be larger than those obtained in longer time scale and larger domain size simulations. This is true when comparing to the finding of Wang et al. (2011), who report average $N_{\mathrm{d}}$ of $65 \mathrm{mg}^{-1}$ and $46 \mathrm{mg}^{-1}$ for their precipitating cases (where $1 \mathrm{mg}^{-1}$ is equal to $1 \mathrm{~cm}^{-3}$ for an air density of $\left.1 \mathrm{~kg} \mathrm{~m}^{-3}\right)$. As there was no precipitation to prevent, no precipitation change occurred (Table 2). The LWP changes were small (up to $2 \%$ ), with small losses during the NP-Ch morning. Cloud fraction, cloud top and cloud base heights all showed negligible perturbations. Whilst the magnitudes of $\Delta \alpha_{\mathrm{CC}}$ were generally significantly smaller for the NP cases compared to the WP cases, these were also sensitive to the timing of injection. For NP-Pa no perturbation was produced for mid-morning injection, although a $\Delta \alpha_{\mathrm{CC}}$ of 0.04 resulted from early morning injection. This peak value was only $13 \%$ of the maximum $\Delta \alpha_{\mathrm{CC}}$ reached when injecting into the WP cloud. For the more heavily polluted NP-Ch case, the pattern was repeated, although where $\Delta \alpha_{\mathrm{CC}}$ occur, the magnitude was less than half that of the NP-Pa case.

The $\Delta \alpha_{\mathrm{AS}}$ was similarly significantly lower than for the WP case. The maximum $\Delta \alpha_{\text {AS }}$ obtained for the NP cases occurred for injection into the day (0.02) and was around a sixth of that achieved in the WP case. The values of $\Delta \alpha_{\mathrm{AS}}$ were similar for both NP cases. The $\Delta \alpha_{\mathrm{CS}}$ followed the same alternating pattern as that of the WP case, with higher perturbations in the early morning and day.

\subsubsection{Rate of aerosol injection into WP case}

For early and mid morning injection into the WP case, $N_{\mathrm{d}}$ increased with injection rate. However, the relationship was non-linear and tended to flatten at higher aerosol injection 


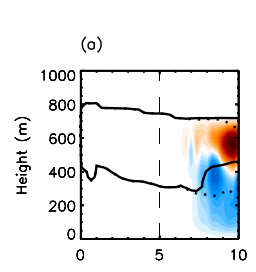

(b)
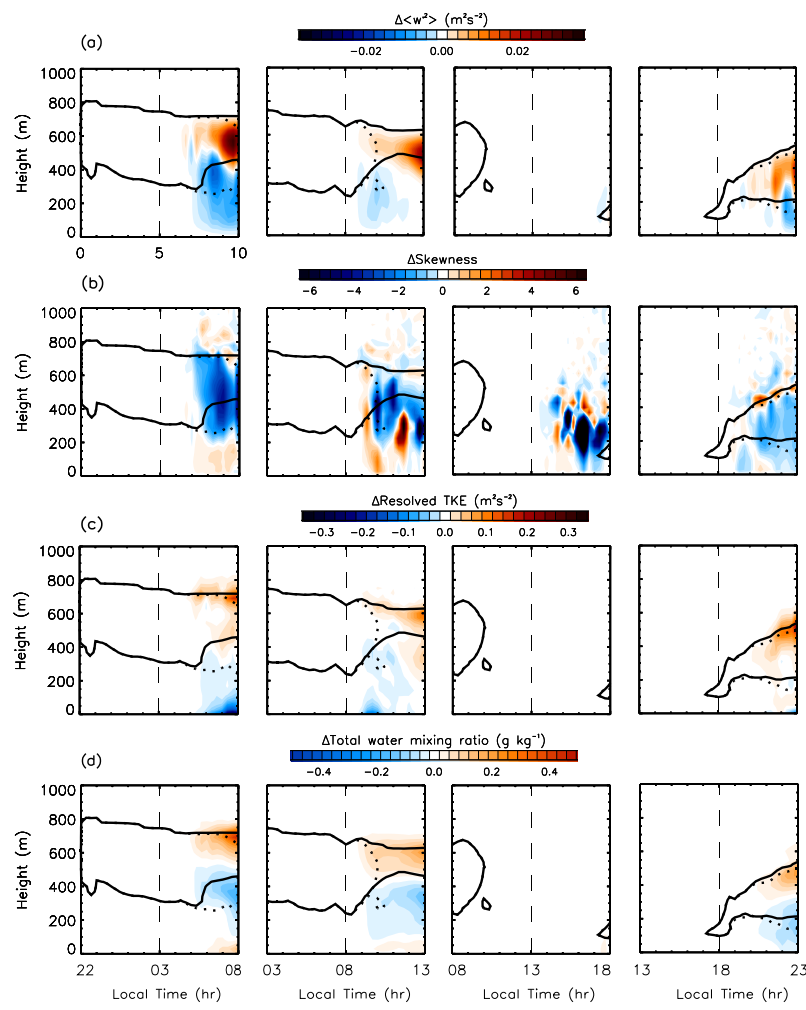

Fig. 6. Time evolution for WP SA0.5 injection-induced perturbations in domain averaged: (a) vertical velocity variance $\left(<w^{\prime 2}\right\rangle$, $\mathrm{m}^{2} \mathrm{~s}^{-2}$ ); (b) vertical velocity skewness; (c) resolved turbulent kinetic energy $\left(\mathrm{m}^{2} \mathrm{~s}^{-2}\right)$; and (d) total water mixing ratio $\left(\mathrm{g} \mathrm{kg}_{\text {dry air }}^{-1}\right)$. Solid lines indicate the perturbed domain average cloud top and base (contour at cloud water mixing ratio of $0.01 \mathrm{~g} \mathrm{~kg}_{\mathrm{dry}}^{-1}$ air $)$. Control case domain average cloud top and base are indicated by the dotted lines. The dashed vertical lines indicate the time of aerosol injection.

rates (Table 3). The opposite relationship occurred for day and evening injections, with decreasing $N_{\mathrm{d}}$ as aerosol injection rates increased. Precipitation rates were uniformly reduced across all injection rates for the early and midmorning. The LWP showed small increases with aerosol injection rates for the early and mid morning injection times, as did the cloud fraction. The $\Delta \alpha_{\mathrm{CC}}$ also increased with increasing aerosol injection rates for both the early and mid morning injections (Fig. 9). This relationship was non-linear, showing a flattening gradient at higher aerosols injection rates. For example, the rate of $\Delta \alpha_{\mathrm{CC}}$ increase with respect to increase in injection rate reduced to a third for the higher injection rates (SA0.25 to SA0.5) into the cloud in the mid-morning compared to the lower injection rates (SA0.1 to SA0.25). This reduction was just under a half for injection into the early morning cloud. Injecting into the cloud-free conditions of the WP early afternoon produced no $\Delta \alpha_{\mathrm{CC}}$, regardless of aerosol concentration. Increasing the injection rate between SA0.1
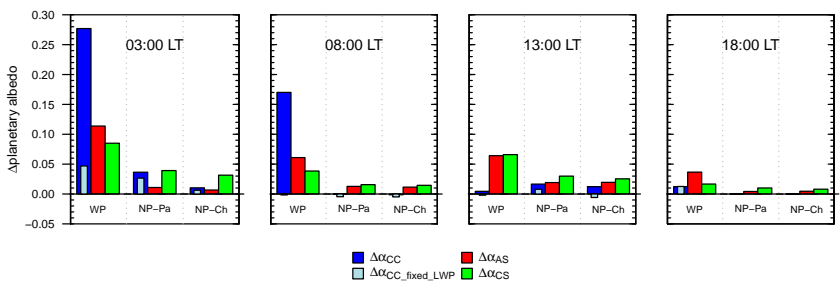

Fig. 7. Domain and time averaged albedo perturbations associated with aerosol injection at the SA0.5 rate, at 03:00:00 LT, 08:00:00 LT, 13:00:00 LT and 18:00:00 LT into the weakly precipitating regime (WP) and non-precipitating regime (NP-Pa and NP-Ch). In each case, four measures of the effects of aerosol injection on albedo perturbations are shown: the change in cloud albedo $\left(\Delta \alpha_{\mathrm{CC}}\right)$; the change in cloud albedo assuming a LWP fixed at the control magnitudes with weighted $N_{\mathrm{d}}$ increases ( $\Delta \alpha_{\mathrm{CC} \_ \text {fixed_LWP }}$ ); the change in all-sky planetary albedo $\left(\Delta \alpha_{\mathrm{AS}}\right)$; and the change in clear-sky albedo $\left(\Delta \alpha_{\mathrm{CS}}\right)$.
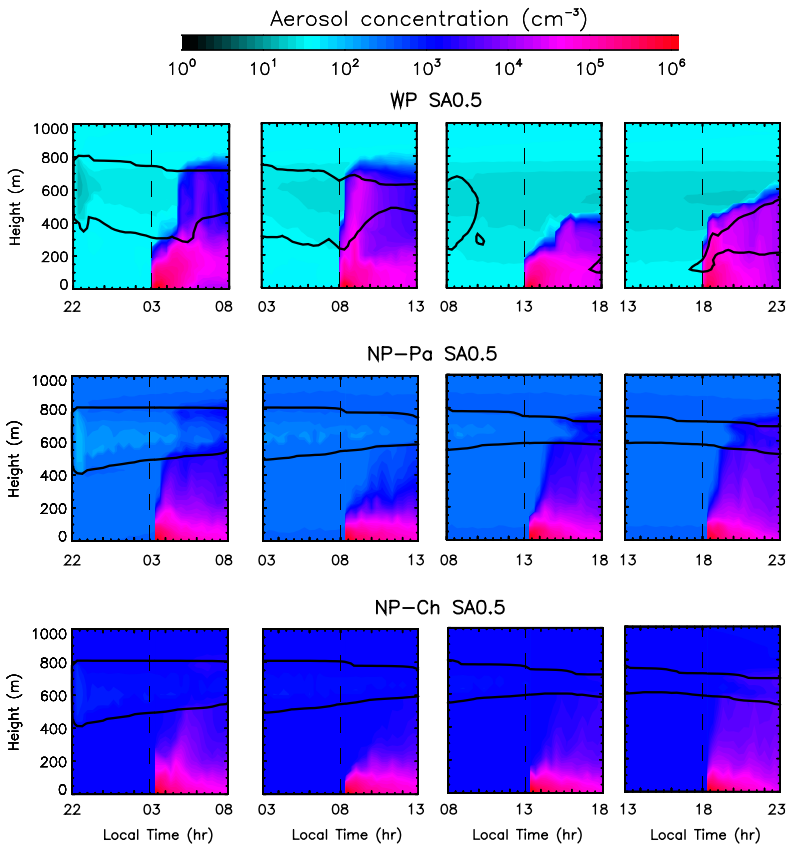

Fig. 8. Time series of domain maximum aerosol concentrations $\left(\mathrm{cm}^{-3}\right)$ for the WP, NP-Pa and NP-Ch cases (all SA0.5 aerosol injection rate). Plots include $5 \mathrm{~h}$ prior to injection and $5 \mathrm{~h}$ subsequent to injection, with aerosol injection start time being indicated by the vertical dashed line.

and SA0.5 also had little effect on $\Delta \alpha_{\mathrm{CC}}$ when injecting into the recovering evening cloud.

The effect of increasing the aerosol injection rates on $\Delta \alpha_{\mathrm{AS}}$ also varied through the diurnal cycle. The $\Delta \alpha_{\mathrm{AS}}$ showed a positive correlation with increasing injection for early and mid morning injection. Again, the rate of $\Delta \alpha_{\mathrm{AS}}$ increase with injection rate was non-linear, the gradient of the response typically halving for the higher injection rates. 
Table 3. Results for the weakly precipitating (WP) case. Notes as Table 2.

\begin{tabular}{llrrrr}
\hline $\begin{array}{l}\text { Time of aerosol } \\
\text { injection (LT) }\end{array}$ & Case & $\begin{array}{r}\text { LWP, } \\
\mathrm{g} \mathrm{m}^{-2}\end{array}$ & $\begin{array}{r}f_{\mathrm{c}}, \\
\%\end{array}$ & $\begin{array}{r}N_{\mathrm{d}}, \\
\mathrm{cm}^{-3}\end{array}$ & $\begin{array}{r}R_{\mathrm{r}}, \\
\mathrm{mm} \mathrm{day}^{-1}\end{array}$ \\
\hline 03:00:00 & Control & 31.8 & 37.9 & 10.8 & 0.25 \\
& SA0.5 & 45.3 & 76.3 & 176.3 & 0.03 \\
& SA0.25 & 44.6 & 73.0 & 141.5 & 0.04 \\
08:00:00 & SA0.1 & 44.1 & 69.7 & 92.9 & 0.04 \\
& Control & 7.0 & 6.8 & 13.5 & 0.09 \\
& SA0.5 & 15.2 & 19.8 & 234.3 & 0.05 \\
& SA0.25 & 14.4 & 17.5 & 200.3 & 0.05 \\
13:00:00 & SA0.1 & 13.1 & 14.6 & 124.4 & 0.06 \\
& Control & 0.6 & 0.4 & 20.6 & 0.00 \\
& SA0.5 & 0.5 & 0.3 & 116.9 & 0.00 \\
18:00:00 & SA0.25 & 0.5 & 0.3 & 134.7 & 0.00 \\
& SA0.1 & 0.5 & 0.4 & 181.6 & 0.00 \\
& Control & 3.6 & 5.6 & 19.5 & 0.00 \\
& SA0.5 & 3.6 & 5.6 & 171.1 & 0.00 \\
& SA0.25 & 3.6 & 5.6 & 180.6 & 0.00 \\
& SA0.1 & 3.6 & 5.6 & 139.9 & 0.00 \\
\hline
\end{tabular}

This relationship was again weaker for the evening, with little variation in the $\Delta \alpha_{\mathrm{AS}}$ for different injection rates. The $\Delta \alpha_{\mathrm{CS}}$ again showed a non-linearly increasing response.

\section{Discussion}

The combination of horizontal and vertical resolutions, and environmental inputs used in these simulations produce diurnal cycles of radiative heating, cloud properties and dynamics that are characteristic of MSc.

Sensitivity testing of model resolution and domain size suggests that the enhancement of horizontal resolution from $300 \mathrm{~m}$ to $100 \mathrm{~m}$ improves recovery of LWP into the second night. However, computational restrictions would require such a resolution to be run over a smaller domain size than currently used, further limiting the aerosol injection analysis time. Increasing the horizontal and vertical resolutions from $300 \mathrm{~m}$ and $\sim 30 \mathrm{~m}$ to $100 \mathrm{~m}$ and $\sim 15 \mathrm{~m}$ resulted in a poorer recovery of LWP and cloud fraction, suggesting that the combination of input soundings, large-scale atmospheric features and radiative response of the cloud case examined did not benefit from the increased resolution as would be expected. Similarly, increasing the vertical resolution from $20 \mathrm{~m}$ to $5 \mathrm{~m}$ did not induce significant improvements in cloud response in the sensitivity study of Chen et al. (2011). In spite of the vertical model resolution being larger than the 5-10 m typically suggested for resolved entrainment (e.g. Bretherton et al., 1999; Stevens and Bretherton, 1999), diurnal variations in entrainment (exhibited as cloud top height variations, given the constant large-scale divergence) behave as expected, with decreases in entrainment during the day in response to weakening cloud top negative buoyancy, and increased entrain-

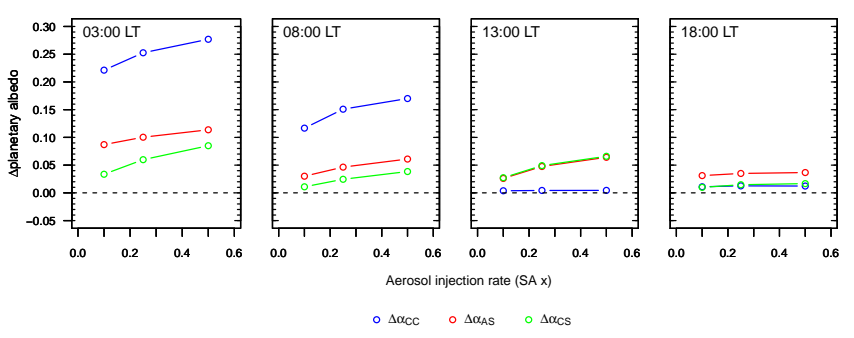

Fig. 9. Domain and time average albedo perturbations associated with SA0.1, SA0.25 and SA0.5 aerosol injection rates at 03:00:00 LT, 08:00:00 LT, 13:00:00 LT and 18:00:00 LT into the weakly precipitating (WP) regime. In each case, three measures of the effects of aerosol injection on albedo perturbations are shown: the change in cloud albedo $\left(\Delta \alpha_{\mathrm{CC}}\right)$; the change in all-sky planetary albedo $\left(\Delta \alpha_{\mathrm{AS}}\right)$; and the change in clear-sky albedo $\left(\Delta \alpha_{\mathrm{CS}}\right)$.

ment rates following the injection-induced $N_{\mathrm{d}}$ increases in the WP case (Fig. 5).

Under the initialisation of wind speed to zero, maximum base-layer wind speeds produced by the convergence of downdrafts reach $2 \mathrm{~m} \mathrm{~s}^{-1}$. These are lower than the 5 to $10 \mathrm{~m} \mathrm{~s}^{-1}$ wind speeds typical of MSc regions (Fan et al., 2012). Thus, while the resulting surface heat fluxes exhibit a diurnal cycle, they are relatively small (cf. measured nocturnal surface heat fluxes of $93 \mathrm{~W} \mathrm{~m}^{-2}$ (latent) and $16 \mathrm{~W} \mathrm{~m}^{-2}$ (sensible) from DYCOMS-II RF02, Ackerman et al., 2009). In the LES MSc modelling of Chen et al. (2011), cloud properties were found to be less sensitive to changes in wind speed than to other environmental settings, including sea-surface temperature, free-tropospheric moisture, and the strength of large-scale subsidence. As demonstrated in our results, while our surface fluxes are relatively low, they are sufficient to maintain cloud during the WP night and NP night and day, and to allow a pattern of rebuilding into the second night in both regimes.

The albedo response to aerosol injection for the WP regime is significantly larger than for the NP regime, in agreement with the results of Wang et al. (2011). Whilst aerosol injection into both the NP and WP regimes demonstrate the first indirect aerosol effect (Twomey, 1977), only aerosol injection into precipitation in the WP regime (i.e. early and mid morning) demonstrates a strong second indirect aerosol, or "lifetime", effect (Albrecht, 1989). The LWP increases associated with this second indirect aerosol effect and negative radiative forcing are more effective at increasing the $\Delta \alpha_{\mathrm{CC}}$ than the first indirect effect, again in agreement with Wang et al. (2011). However, there is no significant second indirect aerosol effect when injecting into the WP regime cloud-free early afternoon or into the WP regime evening where the cloud is in a period of regrowth and has not recovered sufficiently for precipitation.

The LWP increases in the WP regime, and small decreases in LWP in the NP regime illustrate the complexities and 
uncertainties surrounding the magnitude - and sign - of the second indirect aerosol effect. The slight LWP losses for the early and mid morning aerosol injections in the NP-Ch case suggest a small positive second indirect aerosol effect. The LWP response to additional aerosols depends on comparative gains in water from the suppression of precipitation caused by the reduced coalescence of smaller droplets, and increased entrainment drying resulting from the presence of smaller cloud droplets in the entrainment zone and increased TKE (Ackerman et al., 2004). The net effect on LWP is therefore highly dependent on conditions, including cloud base height, precipitation rates, free troposphere moisture content and the mesoscale cloud regime (Ackerman et al., 2004; Wood, 2007; Wang et al., 2011; Christensen and Stephens, 2012). Using a fluid dynamics model, Ackerman et al. (2004) identified a threshold surface precipitation rate of $0.1 \mathrm{~mm}^{\text {day }}{ }^{-1}$, above which LWP increases from precipitation suppression exceed losses from entrainment drying evaporation. However, if the entrained overlying air was drier, net LWP loses were more likely. Using a mixed-layer model, Wood (2007) showed that the cloud-base height was important in distinguishing between clouds that lose or gain LWP in response to aerosol increases, finding a threshold cloud base height of $400 \mathrm{~m}$. Below this height, cloud thickening occurred. Above this height, cloud thinning occurred. This $400 \mathrm{~m}$ cloud base threshold holds for the disparity in LWP response between our WP and NP regimes, suggesting that the LWP increases resulting from precipitation suppression in the WP case were sufficient to overcome the increased evaporation of cloud droplets that resulted in small LWP losses in the NP case. While our simulations therefore produce an interesting range of responses to the injection of aerosol, they are a small subset of possible cloud conditions.

Whilst the detailed consideration of the comparative size distributions of injected and background aerosols and their effect on planetary albedo change is outside of the scope of this paper, we do not see the losses in $N_{\mathrm{d}}$ in response to aerosol injection that were observed in the global aerosol modelling of Korhonen et al. (2010). They showed that, particularly off the coast in the North-East Pacific, activation of injected $260 \mathrm{~nm}$ aerosols suppressed supersaturation, leading to fewer smaller aerosols being activated and the minimum activated aerosol size increasing from $\sim 75-85 \mathrm{~nm}$ to $\sim 110$ $140 \mathrm{~nm}$. By varying the size distribution of the background aerosol initialisations (Fig. 1), this interesting phenomenon could be investigated in future simulations.

GCM simulations have found that the lifetime of the injected aerosols is up to 4.8 days (Jones and Haywood, 2012). Whilst our focus is on the rapid cloud responses to aerosol injection, particularly contrasting the cloud responses at different times in the diurnal cycle, we can infer insights into longer time-frame cloud changes from our simulations. Changes in cloud properties suggest that the injected WP cloud is undergoing a regime change to a more persistent, non-precipitating cloud type. In addition to increases in LWP, the cloud-top height is maintained (in place of control case cloud-top height decrease) for injection into the early and mid morning, and the clouds persist into the day, where enhanced albedo is important for reflection of SW radiation. The cloud top height increases are consistent with those observed by Christensen and Stephens (2011) for ship tracks in the open cellular regime. The indication of regime change is also evident in changes to the vertical velocity skewness as the positive cloud-top skewness of the control case becomes more negative after injection (Fig. 6b). The effectiveness of this morning injection is consistent with the hypothesis proposed by Wang et al. (2011). Whilst the immediate impact of aerosol injection into the clouds in the evening is reduced owing to the lack of SW radiation, regime change may continue through the night, persisting into the subsequent day. Indicators of regime change do not occur for injection into the cloud-free early afternoon, regardless of aerosol injection rate. The lack of rapid cloud response for daytime injection may allow the aerosols to disperse horizontally within the boundary before being drawn into the cloud region by updrafts during the subsequent night. As the aerosols will then cover a larger horizontal extent, the local concentration of aerosols will be diminished, and the pattern of aerosol uptake will be altered. For example, Wang et al. (2011) found that albedo enhancement was larger for uniform compared to point source injection in their weakly precipitating case, however, the converse was true in a more heavily precipitating case. For our NP regime, no indicators of regime change occur for aerosol injection at any time.

Considering the effect of aerosol injection on planetary albedo changes in the WP case suggests that an asymptotic limit in increasing the $\Delta \alpha_{\mathrm{AS}}$ may lie above SA0.5 (Fig. 9). Injection rates greater than SA0.5 led to unphysical model outputs and simulation failure. This demonstrates that the large aerosol fluxes proposed in order to cover large areas of the ocean produce an extreme response if emitted from a point source. The effects of these locally high aerosol concentrations prior to dispersion are not considered in the uniform aerosol application assumed in global models.

The disparities between calculated $\Delta \alpha_{\mathrm{CC}}$ and $\Delta \alpha_{\mathrm{AS}}$ in the WP case for early and mid-morning injections (Figs. 7 and 9) suggests that the large $\Delta \alpha_{\mathrm{CC}}$ are not being fully achieved in the planetary albedo response. We suggest that the high concentration of aerosols emitted via the point source injection technique contribute towards this disparity through an offsetting/tempering effect. The high concentration of injected aerosols emitted from the point source produced large increases in cloud droplet number concentration, particularly in the early/mid morning and evening WP cases (Table 3). These increases cause cloud-top radiative cooling to strengthen, leading to intensification of cloudtop turbulence and the entrainment of dry air from the free troposphere above (evidenced by the increase in cloud top height). This entrainment of warm, dry air increases the evaporation of cloud droplets, leading to the accumulation of 
interstitial aerosols overlying the cloud top (Fig. 8). The seasalt aerosols modelled here are highly scattering, but nonabsorbing in the ultra-violet/visible wavelengths. Whilst a layer of pure $\mathrm{NaCl}$ would therefore typically not be associated with a reduction in planetary albedo when overlying clouds, several factors could cause these overlying aerosols to reduce the upward SW radiation at the top of the atmosphere. Radiative transfer modelling of atmospheric concentrations of non-absorbing sea-salt aerosol overlying a low surface albedo (0.1) have produced a positive SW forcing of up to $+5 \mathrm{~W} \mathrm{~m}^{-2}$ for solar zenith angles of up to $30^{\circ}$ (Li et al., 2008) (equivalent to between 10:00:00 LT and 14:00:00 LT in our simulations). Here, the predominantly forward scattering of the sea-salt aerosols causes the majority of the SW radiation to pass through the aerosol layer, with the magnitude of SW radiation being reflected back to space being reduced by near-infrared absorption, at which wavelengths sea-salt aerosols are more absorbing than in the ultraviolet/ visible wavelengths (Hatzianastassiou et al., 2007). The presence of absorbing material in the sea-salt aerosol would exacerbate the effect, with previous modelling and observational studies showing that partially absorbing aerosols overlying clouds reduce the measured upward irradiance and hence produce low biases in satellite retrievals of cloud optical depth (Haywood et al., 2004; Coddington et al., 2010). A radiatively positive effect was also shown in the modelling of mildly absorbing organic aerosols internally mixed in sea-salt aerosols at mass fractions as low as $10 \%$ (Randles et al., 2004). Attenuation of upward radiation may also result from increases in total water mixing ratio above the cloud top (Fig. 6d), associated with the transported aerosols.

The apparent offsetting/tempering role of the direct effect increases with increasing injection rate, demonstrated by the increasing disparity between $\Delta \alpha_{\mathrm{CC}}$ and $\Delta \alpha_{\mathrm{AS}}$ in the early and mid morning cases (Fig. 9). However, this is not sufficient to overcome the increasing $\Delta \alpha_{\mathrm{CC}}$ and $\Delta \alpha_{\mathrm{AS}}$ with aerosol injection rate (Fig. 9). As simulations carried out at the global scale are unable to represent the locally high aerosol concentrations associated with an aerosol point source, they are unable to simulate this effect.

The ultimate challenge for the geoengineering modelling community is in incorporating the sensitivities to potential implementation details into GCM simulations, in order to continue the development of increasingly realistic global estimates of MCB effectiveness, which are essential for discussions and decision-making. The results presented here are an indication of the rapid cloud response at a small scale to aerosol injection into MSc clouds at different times in the diurnal cycle. Future investigation into this aerosol timing sensitivity should ideally incorporate: domain sizes large enough to simulate cellular cloud patterns and mesoscale feedbacks; a comprehensive range of cloud properties (including variations of cloud-top height, temperature and moisture jumps across the inversion and large-scale subsidence etc.); and a time-scale long enough to capture the full aerosol lifetime.

\section{Conclusions}

Simulations were carried out using a cloud-resolving model at small domain size. These were used to investigate the detailed response of MSc cloud systems to the injection of aerosols at different times during the diurnal cycle, and to investigate the effects and interactions of the direct aerosol effect resulting from the concentrated injection of aerosols from a point source.

Based on these simulations, the optimal point in the diurnal cycle for all-sky planetary albedo response is early morning injection into the weakly precipitating cloud regime. This results from a large second indirect aerosol effect that would contribute to a more negative radiative forcing and cloud conversion towards the more persistent non-precipitating regime. Whilst the direct aerosol effect increases all-sky planetary albedo during the cloud-free early afternoon, the lack of cloud changes suggests that this enhancement may be shorter-lived. The high local concentrations of aerosols (associated with the point source injection) leads to changes in the cloud system that cause interstitial aerosols to accumulate above the cloud. The direct effect of these overlying aerosols appears to mask (or temper) increases in cloud albedo.

The sensitivity of all-sky planetary albedo change to aerosol injection time during the diurnal cycle - particularly for the weakly precipitating regime - suggests that studies that omit this feature may overestimate all-sky planetary albedo increases, although the presence of a direct aerosol effect at cloud-free times would ameliorate this.

Future cloud-resolving modelling, at larger domain sizes and over longer analysis periods is suggested, in order to capture the complex dynamical feedbacks associated with MSc and to quantify the persistence of clouds and aerosol lifetime after point source injection. The ultimate aim is to integrate these characteristic stratocumulus cloud sensitivities into global scale modelling in order to contribute to the continuing improvements in productions of realistic MCB effectiveness estimates that are essential in climate change discussions and decision-making.

In any discussion of the effectiveness of geoengineering in altering climate properties, it is necessary to emphasize the importance of the concomitant examination of ethical validity and governance. However, debate and decision-making must be informed by realistic model simulations, particularly given the strict limitations imposed on field testing. The development of realistic model simulations involves the representation of physical implementation details, particularly those that might act to limit the scheme's effectiveness. Here, the all-sky planetary albedo was found to be sensitive to both the timing of the injection with respect to the cloud diurnal cycle and the high concentration of aerosol resulting from point source emission. Both of these would occur should a single injection vessel be used to cover a large area of cloud. The results suggest that omitting either of these details in simulations may lead to overestimates of the achievable 
increase in all-sky planetary albedo. The results presented here therefore have implications on both the future design of model simulations, and may also inform the development of potential implementation strategies.

Acknowledgements. This research has been funded by the EPSRC and NERC through the "Integrated Assessment of Geoengineering Proposals" (IAGP, http://www.iagp.ac.uk). P. M. F. is additionally supported by a Royal Society Wolfson Merit Award. A. K. L. J. is supported through a Met Office CASE studentship and wishes to thank Andy Jones, Ed Pitt and members of her Research Support Group for their comments and guidance. The authors would like to thank: Kirsty Pringle for the provision of GLOMAP data; Douglas Lowe and the Manchester group for the provision of the sea-salt emission parameterisation and advice with model usage; Steven Pickering; Hailong Wang and members of the Physical Climate Change Group for their helpful suggestions and support.

Edited by: A. Geer

\section{References}

Abdul-Razzak, H. and Ghan, S. J.: A parameterization of aerosol activation 2. Multiple aerosol types, J. Geophys. Res., 105, 68376844, doi:10.1029/1999jd901161, 2000.

Ackerman, A. S., Kirkpatrick, M. P., Stevens, D. E., and Toon, O. B.: The impact of humidity above stratiform clouds on indirect aerosol climate forcing, Nature, 432, 1014-1017, 2004.

Ackerman, A. S., vanZanten, M. C., Stevens, B., Savic-Jovcic, V., Bretherton, C. S., Chlond, A., Golaz, J.-C., Jiang, H., Khairoutdinov, M., Krueger, S. K., Lewellen, D. C., Lock, A., Moeng, C.-H., Nakamura, K., Petters, M. D., Snider, J. R., Weinbrecht, S., and Zulauf, M.: Large-Eddy Simulations of a Drizzling, Stratocumulus-Topped Marine Boundary Layer, Mon. Weather Rev., 137, 1083-1110, doi:10.1175/2008MWR2582.1, 2009.

Albrecht, B. A.: Aerosols, Cloud Microphysics, and Fractional Cloudiness, Science, 245, 1227-1230, doi:10.1126/science.245.4923.1227, 1989.

Albrecht, B. A., Randall, D. A., and Nicholls, S.: Observations of Marine Stratocumulus Clouds During FIRE, B. Am. Meteorol. Soc., 69, 618-626, doi:10.1175/15200477(1988)069<0618:oomscd > 2.0.co;2, 1988.

Bretherton, C. S., Macvean, M. K., Bechtold, P., Chlond, A., Cotton, W. R., Cuxart, J., Cuijpers, H., Mhairoutdinov, M., Kosovic, B., Lewellen, D., Moeng, C. H., Siebesma, P., Stevens, B., Stevens, D. E., Sykes, I., and Wyant, M. C.: An intercomparison of radiatively driven entrainment and turbulence in a smoke cloud, as simulated by different numerical models, Q. J. Roy. Meteorol. Soc., 125, 391-423, 10.1002/qj.49712555402, 1999.

Bretherton, C. S., Uttal, T., Fairall, C. W., Yuter, S. E., Weller, R. A., Baumgardner, D., Comstock, K., Wood, R., and Raga, G. B.: The Epic 2001 Stratocumulus Study, B. Am. Meteorol. Soc., 85, 967-977, doi:10.1175/BAMS-85-7-967, 2004.

Chen, Y.-C., Xue, L., Lebo, Z. J., Wang, H., Rasmussen, R. M., and Seinfeld, J. H.: A comprehensive numerical study of aerosolcloud-precipitation interactions in marine stratocumulus, Atmos. Chem. Phys., 11, 9749-9769, doi:10.5194/acp-11-9749-2011, 2011.
Chlond, A., Müller, F., and Sednev, I.: Numerical simulation of the diurnal cycle of marine stratocumulus during FIRE - An LES and SCM modelling study, Q. J. Roy. Meteorol. Soc., 130, 32973321, doi:10.1256/qj.03.128, 2004.

Christensen, M. W. and Stephens, G. L.: Microphysical and macrophysical responses of marine stratocumulus polluted by underlying ships: Evidence of cloud deepening, J. Geophys. Res., 116, D03201, doi:10.1029/2010jd014638, 2011.

Christensen, M. W. and Stephens, G. L.: Microphysical and macrophysical responses of marine stratocumulus polluted by underlying ships: 2. Impacts of haze on precipitating clouds, J. Geophys. Res., 117, D11203, doi:10.1029/2011jd017125, 2012.

Coddington, O. M., Pilewskie, P., Redemann, J., Platnick, S., Russell, P. B., Schmidt, K. S., Gore, W. J., Livingston, J., Wind, G., and Vukicevic, T.: Examining the impact of overlying aerosols on the retrieval of cloud optical properties from passive remote sensing, J. Geophys. Res., 115, D10211, doi:10.1029/2009jd012829, 2010.

Collins, W. D., Rasch, P. J., Boville, B. A., Hack, J. J., McCaa, J. R., Williamson, D. L., Kiehl, J. T., Briegleb, B., Bitz, C., Lin, S.-J., Zhang, M., and Dai, Y.: Description of the NCAR Community Atmosphere Model (CAM 3.0), NCAR Technical Note, NCAR/TN-464+STR, 2004.

Duynkerke, P. G. and Teixeira, J.: Comparison of the ECMWF Reanalysis with FIRE I Observations: Diurnal Variation of Marine Stratocumulus, J. Climate, 14, 1466-1478, doi:10.1175/15200442(2001)014<1466:coterw>2.0.co;2, 2001.

Duynkerke, P. G., de Roode, S. R., van Zanten, M. C., Calvo, J., Cuxart, J., Cheinet, S., Chlond, A., Grenier, H., Jonker, P. J., Köhler, M., Lenderink, G., Lewellen, D., Lappen, C.-1., Lock, A. P., Moeng, C.-h., Müller, F., Olmeda, D., Piriou, J.-m., Sánchez, E., and Sednev, I.: Observations and numerical simulations of the diurnal cycle of the EUROCS stratocumulus case, Q. J. Roy. Meteorol. Soc., 130, 3269-3296, doi:10.1256/qj.03.139, 2004.

Fan, Y., Lin, S.-J., Held, I. M., Yu, Z., and Tolman, H. L.: Global Ocean Surface Wave Simulation Using a Coupled AtmosphereWave Model, J. Climate, 25, 6233-6252, doi:10.1175/jcli-d-1100621.1, 2012.

Fast, J. D., Gustafson, W. I., Jr., Easter, R. C., Zaveri, R. A., Barnard, J. C., Chapman, E. G., Grell, G. A., and Peckham, S. E.: Evolution of ozone, particulates, and aerosol direct radiative forcing in the vicinity of Houston using a fully coupled meteorology-chemistry-aerosol model, J. Geophys. Res., 111, D21305, doi:10.1029/2005jd006721, 2006.

Feingold, G., Koren, I., Wang, H., Xue, H., and Brewer, W. A.: Precipitation-generated oscillations in open cellular cloud fields, Nature, 466, 849-852, 2010.

Fuentes, E., Coe, H., Green, D., de Leeuw, G., and McFiggans, G.: On the impacts of phytoplankton-derived organic matter on the properties of the primary marine aerosol - Part 1: Source fluxes, Atmos. Chem. Phys., 10, 9295-9317, doi:10.5194/acp-10-92952010, 2010.

Georgii, H. W. and Gravenhorst, G.: The ocean as source or sink of reactive trace-gases, Pure Appl. Geophys., 115, 503-511, doi:10.1007/bf00876117, 1977.

Gray, B., Wang, Y., Gu, D., Bandy, A., Mauldin, L., Clarke, A., Alexander, B., and Davis, D.: Sources, transport, and sinks of $\mathrm{SO}_{2}$ over the equatorial Pacific during the Pacific Atmospheric Sulfur Experiment, J. Atmos. Chem., 68, 27-53, 
doi:10.1007/s10874-010-9177-7, 2011.

Hatzianastassiou, N., Matsoukas, C., Fotiadi, A., P. W. Stackhouse Jr., Koepke, P., Pavlakis, K. G., and Vardavas, I.: Modelling the direct effect of aerosols in the solar near-infrared on a planetary scale, Atmos. Chem. Phys., 7, 3211-3229, doi:10.5194/acp-73211-2007, 2007.

Haywood, J. M., Osborne, S. R., and Abel, S. J.: The effect of overlying absorbing aerosol layers on remote sensing retrievals of cloud effective radius and cloud optical depth, Q. J. Roy. Meteorol. Soc., 130, 779-800, doi:10.1256/qj.03.100, 2004.

Hogan, R. J., Grant, A. L. M., Illingworth, A. J., Pearson, G. N., and O'Connor, E. J.: Vertical velocity variance and skewness in clear and cloud-topped boundary layers as revealed by Doppler lidar, Q. J. Roy. Meteorol. Soc., 135, 635-643, doi:10.1002/qj.413, 2009.

Johnson, B. T.: The Semidirect Aerosol Effect: Comparison of a Single-Column Model with Large Eddy Simulation for Marine Stratocumulus, J. Climate, 18, 119-130, doi:10.1175/jcli-3233.1, 2005.

Jones, A. and Haywood, J. M.: Sea-spray geoengineering in the HadGEM2-ES earth-system model: radiative impact and climate response, Atmos. Chem. Phys., 12, 10887-10898, doi:10.5194/acp-12-10887-2012, 2012.

Jones, A., Haywood, J., and Boucher, O.: Climate impacts of geoengineering marine stratocumulus clouds, J. Geophys. Res., 114, D10106, doi:10.1029/2008jd011450, 2009.

Jones, A., Haywood, J., and Boucher, O.: A comparison of the climate impacts of geoengineering by stratospheric $\mathrm{SO}_{2}$ injection and by brightening of marine stratocumulus cloud, Atmos. Sci. Lett., 12, 176-183, doi:10.1002/as1.291, 2011a.

Jones, C. R., Bretherton, C. S., and Leon, D.: Coupled vs. decoupled boundary layers in VOCALS-REx, Atmos. Chem. Phys., 11, 7143-7153, doi:10.5194/acp-11-7143-2011, 2011 b.

Kazil, J., Wang, H., Feingold, G., Clarke, A. D., Snider, J. R., and Bandy, A. R.: Modeling chemical and aerosol processes in the transition from closed to open cells during VOCALS-REx, Atmos. Chem. Phys., 11, 7491-7514, doi:10.5194/acp-11-74912011, 2011.

Khalil, M. A. K. and Rasmussen, R. A.: Global decrease in atmospheric carbon monoxide concentration, Nature, 370, 639-641, 1994.

Korhonen, H., Carslaw, K. S., and Romakkaniemi, S.: Enhancement of marine cloud albedo via controlled sea spray injections: a global model study of the influence of emission rates, microphysics and transport, Atmos. Chem. Phys., 10, 4133-4143, doi:10.5194/acp-10-4133-2010, 2010.

Lacis, A. A. and Hansen, J.: A Parameterization for the Absorption of Solar Radiation in the Earth's Atmosphere, J. Atmos. Sci., 31, 118-133, doi:10.1175/15200469(1974)031<0118:apftao>2.0.co;2, 1974.

Latham, J.: Control of global warming?, Nature, 347, 339-340, doi:10.1038/347339b0, 1990.

Latham, J.: Amelioration of global warming by controlled enhancement of the albedo and longevity of low-level maritime clouds, Atmos. Sci. Lett., 3, 52-58, doi:10.1006/asle.2002.0099, 2002.

Latham, J., Rasch, P., Chen, C.-C., Kettles, L., Gadian, A., Gettelman, A., Morrison, H., Bower, K., and Choularton, T.: Global temperature stabilization via controlled albedo enhancement of low-level maritime clouds, Philosophical Transactions of the
Royal Society A: Mathematical, Physical and Engineering Sciences, 366, 3969-3987, doi:10.1098/rsta.2008.0137, 2008.

Lenton, T. M. and Vaughan, N. E.: The radiative forcing potential of different climate geoengineering options, Atmos. Chem. Phys., 9, 5539-5561, doi:10.5194/acp-9-5539-2009, 2009.

Lewis, E. R. and Schwartz, S. E.: Sea Salt Aerosol Production: Mechanisms, Methods, Measurements and Models: a Critical Review, American Geophysical Union, 2004.

Li, J., Ma, X., von Salzen, K., and Dobbie, S.: Parameterization of sea-salt optical properties and physics of the associated radiative forcing, Atmos. Chem. Phys., 8, 4787-4798, doi:10.5194/acp-84787-2008, 2008.

Lock, A. P.: The sensitivity of a GCM's marine stratocumulus to cloud-top entrainment, Q. J. Roy. Meteorol. Soc., 130, 33233338, doi:10.1256/qj.03.114, 2004.

Mann, G. W., Carslaw, K. S., Spracklen, D. V., Ridley, D. A., Manktelow, P. T., Chipperfield, M. P., Pickering, S. J., and Johnson, C. E.: Description and evaluation of GLOMAP-mode: a modal global aerosol microphysics model for the UKCA composition-climate model, Geosci. Model Dev., 3, 519-551, doi:10.5194/gmd-3-519-2010, 2010.

Minnis, P., Heck, P. W., Young, D. F., Fairall, C. W., and Snider, J. B.: Stratocumulus Cloud Properties Derived from Simultaneous Satellite and Island-based Instrumentation during FIRE, J. Appl. Meteorol., 31, 317-339, doi:10.1175/15200450(1992)031<0317:scpdfs > 2.0.co;2, 1992.

Morrison, H., Curry, J. A., and Khvorostyanov, V. I.: A New Double-Moment Microphysics Parameterization for Application in Cloud and Climate Models. Part I: Description, J. Atmos. Sci., 62, 1665-1677, doi:10.1175/jas3446.1, 2005.

Nieuwstadt, F. T. M. and Duynkerke, P. G.: Turbulence in the atmospheric boundary layer, Atmos. Res., 40, 111-142, doi:10.1016/0169-8095(95)00034-8, 1996.

Partanen, A.-I., Kokkola, H., Romakkaniemi, S., Kerminen, V.-M., Lehtinen, K. E. J., Bergman, T., Arola, A., and Korhonen, H.: Direct and indirect effects of sea spray geoengineering and the role of injected particle size, J. Geophys. Res., 117, D02203, doi:10.1029/2011jd016428, 2012.

Randles, C. A., Russell, L. M., and Ramaswamy, V.: Hygroscopic and optical properties of organic sea salt aerosol and consequences for climate forcing, Geophys. Res. Lett., 31, L16108, doi:10.1029/2004g1020628, 2004.

Rasch, P. J., Latham, J., and Chen, C. C.: Geoengineering by cloud seeding: influence on sea ice and climate system, Environ. Res. Lett., 4, 045112, doi:10.1088/1748-9326/4/4/045112, 2009.

Rozendaal, M. A., Leovy, C. B., and Klein, S. A.: An observational study of diurnal variations of marine stratiform cloud, Journal Name: Journal of Climate; Journal Volume: 8; Journal Issue: 7; Other Information: PBD: Jul 1995, Medium: X; Size: 17951809, 1995.

Saide, P. E., Spak, S. N., Carmichael, G. R., Mena-Carrasco, M. A., Yang, Q., Howell, S., Leon, D. C., Snider, J. R., Bandy, A. R., Collett, J. L., Benedict, K. B., de Szoeke, S. P., Hawkins, L. N., Allen, G., Crawford, I., Crosier, J., and Springston, S. R.: Evaluating WRF-Chem aerosol indirect effects in Southeast Pacific marine stratocumulus during VOCALS-REx, Atmos. Chem. Phys., 12, 3045-3064, doi:10.5194/acp-12-3045-2012, 2012.

Salter, S., Sortino, G., and Latham, J.: Sea-going hardware for the cloud albedo method of reversing global warming, Philos. T. 
Roy. Soc. A, 366, 3989-4006, doi:10.1098/rsta.2008.0136, 2008. Skamarock, W. C., Klemp, J. B., Dudhia, J., Gill, D. O., Barker, D. M., Duda, M. G., Huang, X.-Y., Wang, W., and Powers, J. G.: A Description of the Advanced Research WRF Version 3, NCAR Technical Note, NCAR/TN-475+STR, 2008.

Stevens, B. and Feingold, G.: Untangling aerosol effects on clouds and precipitation in a buffered system, Nature, 461, 607-613, 2009.

Stevens, B., Lenschow, D. H., Vali, G., Gerber, H., Bandy, A., Blomquist, B., Brenguier, J.-L., Bretherton, C. S., Burnet, F., Campos, T., Chai, S., Faloona, I., Friesen, D., Haimov, S., Laursen, K., Lilly, D. K., Loehrer, S. M., Malinowski, S. P., Morley, B., Petters, M. D., Rogers, D. C., Russell, L., SavicJovcic, V., Snider, J. R., Straub, D., Szumowski, M. J., Takagi, H., Thornton, D. C., Tschudi, M., Twohy, C., Wetzel, M., and van Zanten, M. C.: Dynamics and Chemistry of Marine Stratocumulus - DYCOMS-II, B. Am. Meteorol. Soc., 84, 579-593, doi:10.1175/BAMS-84-5-579, 2003.

Stevens, B., Moeng, C.-H., Ackerman, A. S., Bretherton, C. S., Chlond, A., de Roode, S., Edwards, J., Golaz, J.-C., Jiang, H., Khairoutdinov, M., Kirkpatrick, M. P., Lewellen, D. C., Lock, A., Müller, F., Stevens, D. E., Whelan, E., and Zhu, P.: Evaluation of Large-Eddy Simulations via Observations of Nocturnal Marine Stratocumulus, Mon. Weather Rev., 133, 1443-1462, doi:10.1175/MWR2930.1, 2005.

Stevens, D. E. and Bretherton, C. S.: Effects of resolution on the simulation of stratocumulus entrainment, Q. J. Roy. Meteorol. Soc., 125, 425-439, doi:10.1002/qj.49712555403, 1999.

Stubenrauch, C. J., Chédin, A., Rädel, G., Scott, N. A., and Serrar, S.: Cloud Properties and Their Seasonal and Diurnal Variability from TOVS Path-B, J. Climate, 19, 5531-5553, doi:10.1175/jcli3929.1, 2006.

Twomey, S.: The Influence of Pollution on the Shortwave Albedo of Clouds, J. Atmos. Sci., 34, 1149-1152, doi:10.1175/15200469(1977)034<1149:TIOPOT>2.0.CO;2, 1977.

Wang, H. and Feingold, G.: Modeling Mesoscale Cellular Structures and Drizzle in Marine Stratocumulus. Part I: Impact of Drizzle on the Formation and Evolution of Open Cells, J. Atmos. Sci., 66, 3237-3256, doi:10.1175/2009JAS3022.1, 2009a.

Wang, H. and Feingold, G.: Modeling Mesoscale Cellular Structures and Drizzle in Marine Stratocumulus. Part II: The Microphysics and Dynamics of the Boundary Region between Open and Closed Cells, J. Atmos. Sci., 66, 3257-3275, doi:10.1175/2009JAS3120.1, 2009b.
Wang, H., Skamarock, W. C., and Feingold, G.: Evaluation of Scalar Advection Schemes in the Advanced Research WRF Model Using Large-Eddy Simulations of AerosolCloud Interactions, Mon. Weather Rev., 137, 2547-2558, doi:10.1175/2009MWR2820.1, 2009.

Wang, H., Feingold, G., Wood, R., and Kazil, J.: Modelling microphysical and meteorological controls on precipitation and cloud cellular structures in Southeast Pacific stratocumulus, Atmos. Chem. Phys., 10, 6347-6362, doi:10.5194/acp-10-6347-2010, 2010.

Wang, H., Rasch, P. J., and Feingold, G.: Manipulating marine stratocumulus cloud amount and albedo: a process-modelling study of aerosol-cloud-precipitation interactions in response to injection of cloud condensation nuclei, Atmos. Chem. Phys., 11, 4237-4249, doi:10.5194/acp-11-4237-2011, 2011.

Wood, R.: Cancellation of Aerosol Indirect Effects in Marine Stratocumulus through Cloud Thinning, J. Atmos. Sci., 64, $2657-$ 2669, doi:10.1175/JAS3942.1, 2007.

Wood, R. and Hartmann, D. L.: Spatial Variability of Liquid Water Path in Marine Low Cloud: The Importance of Mesoscale Cellular Convection, J. Climate, 19, 1748-1764, doi:10.1175/jcli3702.1, 2006.

Wood, R., Comstock, K. K., Bretherton, C. S., Cornish, C., Tomlinson, J., Collins, D. R., and Fairall, C.: Open cellular structure in marine stratocumulus sheets, J. Geophys. Res., 113, D12207, doi:10.1029/2007jd009371, 2008.

Yang, M., Huebert, B. J., Blomquist, B. W., Howell, S. G., Shank, L. M., McNaughton, C. S., Clarke, A. D., Hawkins, L. N., Russell, L. M., Covert, D. S., Coffman, D. J., Bates, T. S., Quinn, P. K., Zagorac, N., Bandy, A. R., de Szoeke, S. P., Zuidema, P. D., Tucker, S. C., Brewer, W. A., Benedict, K. B., and Collett, J. L.: Atmospheric sulfur cycling in the southeastern Pacific longitudinal distribution, vertical profile, and diel variability observed during VOCALS-REx, Atmos. Chem. Phys., 11, 50795097, doi:10.5194/acp-11-5079-2011, 2011.

Zaveri, R. A. and Peters, L. K.: A new lumped structure photochemical mechanism for large-scale applications, J. Geophys. Res. 104, 30387-30415, doi:10.1029/1999jd900876, 1999.

Zaveri, R. A., Easter, R. C., Fast, J. D., and Peters, L. K.: Model for Simulating Aerosol Interactions and Chemistry (MOSAIC), J. Geophys. Res., 113, D13204, doi:10.1029/2007jd008782, 2008.

Zhang, Y., Stevens, B., and Ghil, M.: On the diurnal cycle and susceptibility to aerosol concentration in a stratocumulustopped mixed layer, Q. J. Roy. Meteorol. Soc., 131, 1567-1583, doi:10.1256/qj.04.103, 2005. 